\title{
Analisis Pengaruh Kinerja Layanan, Kepercayaan, Dan Harga Terhadap Loyalitas Pelanggan Jasa Pos Express Di Kota Padang
}

\author{
Oleh : \\ Eka Permata Putra, Yuni Candra,dan Sepris Yonaldi \\ Program Studi Manajemen Universitas Tamansiswa Padang
}

\begin{abstract}
ABSTRAK
Tujuan penelitian ini dilakukan untuk mengetahui dan menganalisis pengaruh kinerja layanan, kepercayaan, dan harga terhadap loyalitas pelanggan jasa pos express di kota Padang. Hasil survey dilapangan menunjukan bahwa pada tiga tahun terakhir jumlah konsumen yang menggunakan layanan jasa pos express mengalami penurunan. Populasi yang digunakan dalam penelitian ini, berdasarkan pada jumlah pelanggang yang menggunakan jasa pos express tahun 2014 adalah 93.138 orang, dengan jumlah sampel yang diperoleh dari rumus Slovin adalah 100 responden. Teknik pengambilan sampel dalam penelitian ini menggunakan sampling incidental. Alat analisis yang digunakan adalah analisis deskriptif, analisis regresi berganda, uji t, uji $\mathrm{F}$, dan koefesien determinasi. Sebelum dilakukan pengujian berdasarkan alat analisis yang digunakan, terlebih dahulu dilakukan uji validitas dan reliabilitas. Berdasarkan analisis regresi linear berganda didapat persamaan : $\mathrm{Y}=-1,787+0,361 \mathrm{X}_{1}+0,329 \mathrm{X}_{2}+0,237 \mathrm{X}_{3}+\mathrm{e}$. Hasil penelitian menunjukan bahwa kinerja layanan berpengaruh signifikan terhadap loyalitas pelanggan dengan $t_{\text {hitung }} 3,153>\mathrm{t}_{\text {tabel }}$ 1,985. Kepercayaan berpengaruh signifikan terhadap loyalitas pelanggan dengan $t_{\text {hitung }} 4,003>t_{\text {tabel }}$ 1,985. Harga berpengaruh signifikan terhadap loyalitas pelanggan $t_{\text {hitung }} 3,356>$ $t_{\text {tabel }} 1,985$. Kinerja layanan, kepercayaan, dan harga secara simultan (bersamasama) berpengaruh signifikan terhadap loyalitas pelanggan dengan $F_{\text {hitung }} 32,037>$ $F_{\text {tabel }}$ 2,70. Dari hasil koefisien determinasi diketahui kontribusi yang diberikan oleh kinerja layanan, kepercayaan, dan harga terhadap loyalitas pelanggan adalah 48,50\% maka dapat disimpulkan bahwa kemampuan variabel kinerja layanan, kepercayaan, dan harga dalam menjelaskan variabel loyalitas pelanggan sebesar $48,50 \%$.
\end{abstract}

Kata kunci : Kinerja layanan, kepercayaan, harga, dan loyalitas pelanggan

\section{PENDAHULUAN}




\section{Latar Belakang}

Salah satu syarat yang harus dipenuhi oleh perusahaan agar dapat sukses dalam persaingan adalah berusaha untuk menciptakan dan membangun loyalitas pelanggan. Dalam mengelola bisnis berbasis pelanggan, loyalitas pelanggan tentunya diperlukan oleh perusahaan untuk bisa tetap bertahan dan mampu bersaing dengan perusahaan lain. Pelanggan yang loyal merupakan peluang untuk mendapatkan pelanggan baru, mempertahankan semua pelanggan yang ada umumnya akan lebih menguntungkan dibandingkan dengan pergantian pelanggan karena biaya untuk menarik pelanggan baru bisa lima kali lipat lebih besar dari biaya mempertahankan seorang pelanggan yang sudah ada (Kotler, 2000 dalam Murti, 2013 : 111). Hal ini dapat dilihat pada Tabel 1.1

Tabel 1.1.

Jumlah Konsumen Yang Menggunakan Layanan Jasa Pos Express

PT. Pos Indonesia (Persero) Kantor Padang 25000 selama tahun 2010-2014

\begin{tabular}{|c|c|}
\hline Tahun & $\begin{array}{c}\text { Jumlah Konsumen } \\
\text { (Orang) }\end{array}$ \\
\hline 2010 & 54.817 \\
\hline 2011 & 117.561 \\
\hline 2012 & 108.516 \\
\hline 2013 & 107.359 \\
\hline 2014 & 93.138 \\
\hline
\end{tabular}

Sumber : PT. Pos Indonesia (Persero) Padang, 2015

Berdasarkan Tabel 1.1, dapat dilihat bahwa pada periode tahun 2010 hingga 2011, konsumen pengguna jasa pos express mengalami peningkatan yang signifikan. Akan tetapi pada tahun 2012 hingga 2014, konsumen pengguna jasa pos express mengalami penurunan tiap tahunnya. Hal ini mengindikasikan loyalitas pelanggan pengguna jasa pos express mengalami penurunan. Dengan menurunnya jumlah pelanggan, maka pendapatan perusahaan juga menurun, sjika tidak segera diatasi akan mengancam kelangsungan usaha dimasa yang akan datang.

Menghadapi persaingan yang semakin ketat, kualitas layanan yang diterima oleh pelanggan haruslah ditingkatkan oleh perusahaan. Rendahnya kualitas layanan yang diterima dan dirasakan oleh pelanggan akan membawa pengaruh buruk pada perusahaan, dimana pelanggan akan beralih menggunakan jasa pesaing yang memberikan kualitas layanan yang lebih baik. Kualitas suatu layanan jasa, menurut Cronin dan Taylor (1994) dikutip Fandy (1994) dalam Mulyana dan Sufiyanor (2009:74) diukur berdasarkan perceived performance dari suatu jasa, yang dikenal dengan model SERVPERF (service performance).

Cronin dan Taylor (1994) dalam Mulyana dan Sufiyanor (2009 : 83), "service performance merupakan kinerja dari pelayanan yang diterima oleh konsumen itu sendiri dan menilai kualitas dari pelayanan yang benar-benar mereka rasakan". Dalam hal ini, ukuran layanan yang berdasarkan kinerja akan lebih merefleksikan kualitas jasa/pelayanan (Dharmayanti, 2006 : 35-36). 
Menurut Nugroho (2013 : 2), "semakin mampu perusahaan tersebut menunjukan kinerja layanan, maka akan semakin menambah tingkat loyalitas pelanggan”.

Meningkatnya jumlah pelanggan yang komplain pada layanan jasa pos express dapat mengakibatkan kepercayaan pelanggan terhadap layanan jasa pos express jadi berkurang. Hasil pengamatan penulis terhadap 10 pelanggan yang melakukan komplain atas layanan jasa pos express pada customer service, dimana terdapat 7 orang yang tidak percaya dengan layanan jasa pos express dan 3 orang masih mempercayai layanan jasa pos express. Akibat dari kurangnya kepercayaan pelanggan terhadap layanan jasa pos express dapat menyebabkan pelanggan akan beralih menggunakan jasa pesaing lainnya dan tidak memilih layanan jasa pos express sebagai pilihan utama dalam kebutuhan pengiriman barang dan dokumen. Hal ini tentunya akan membahayakan perusahaan ditengah ketatnya persaingan jasa pengiriman barang dan dokumen saat ini.

Dalam meningkatkan loyalitas pelanggan, harga perlu menjadi evaluasi bagi perusahaan. Menurut Kurniasih (2012 : 44), "harga mempunyai pengaruh positif dan signifikan terhadap loyalitas pelanggan”. Meningkatnya pelanggan yang komplain pada layanan jasa pos express mengakibatkan harga yang dibayarkan pelanggan tidak sesuai dengan pelayanan yang diharapkan. Harga yang tidak sesuai dengan harapan pelanggan terhadap pelayanan yang diterima, dapat mengakibatkan loyalitas pelanggan menurun.

Berdasarkan latar belakang permasalahan, dan melihat uraian-uraian di atas dari pengamatan yang dilakukan penulis maupun fenomena-fenomena yang terjadi, maka menarik dilakukan suatu penelitian dengan judul "Analisis pengaruh Kinerja Layanan, Kepercayaan, dan Harga terhadap Loyalitas Pelanggan Jasa Pos Express di Kota Padang (studi kasus pada Kantor Pos Padang 25000)".

\section{Tujuan Penelitian}

Penelitian ini dilakukan tentunya memiliki tujuan-tujuan tertentu. Adapun yang menjadi tujuan dilakukannya penelitian ini adalah untuk mengetahui pengaruh kinerja layanan, kepercayaan dan harga baik secara parsial maupun simultan (bersama-sama) terhadap loyalitas pelanggan jasa pos express di kota Padang.

\section{Landasan Teori}

\section{a) Manajemen Pemasaran Jasa}

Menurut Lupiyoadi (2006 : 5), "pemasaran jasa adalah setiap tindakan yang ditawarkan oleh salah satu pihak kepada pihak lain yang secara prinsip intangible dan tidak menyebakan perpindah kepemilikan apapun". Pemasaran jasa merupakan suatu tindakan yang ditawarkan pihak produsen kepada konsumen, dalam arti jasa yang diberikan tidak dapat dilihat, dirasa, didengar atau diraba sebelum dikonsumsi.

\section{b) Kinerja Layanan}

Kualitas suatu layanan jasa, menurut Cronin dan Taylor (1994) dikutip Fandi (2004) dalam Mulyana dan Sufiyanor (2009 : 74) diukur berdasarkan 
perceived performance dari suatu jasa, yang dikenal dengan model SERVPERF (service performance). Cronin dan Taylor (1994) dalam Mulyana dan Sufiyanor (2009 : 83), "service performance merupakan kinerja dari pelayanan yang diterima oleh konsumen itu sendiri dan menilai kualitas dari pelayanan yang benar-benar mereka rasakan."

Brady dan Cronin dikutip Caro dan Roermer (2006) dalam Mulyana dan Sufiyanor (2009 : 77), menyatakan bahwa "pelanggan membentuk persepsi terhadap kualitas jasa berdasarkan pada evaluasi performance pada berbagai level, kemudian mengkombinasikan hasil evaluasinya kedalam persepsi kualitas jasa secara keseluruhan". Brady dan Cronin (2001) dalam Fandy dan Chandra (2005) dalam Mulyana dan Sufiyanor (2009 : 78), "berupaya mengintegrasikan dua konseptualisasi pengukuran kualitas jasa yang dominan (model SERVQUAL dan Total Perceived Quality Model) kedalam sebuah kerangka komprehensif dan multidimensional yang berbasis teoretikal kuat".

Berdasarkan telaah literature, riset kualitatif, dan studi validasi pada empat industri jasa (restoran siap saji, jasa cuci cetak foto, taman hiburan, dan drycleaning), Brady dan Cronin (2001) dalam Mulyana dan Sufiyanor (2009 : 78) mengembangkan model kualitas jasa berbasis ancangan hierarkis.

\section{Gambar 2.1.}

\section{Ancangan Hierarkis Persepsi Terhadap Kualitas Jasa}

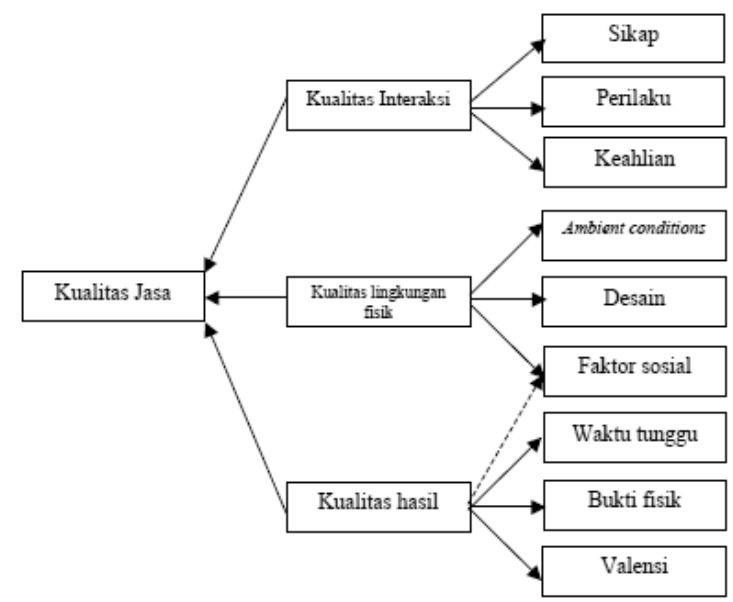

Sumber : Brady dan Cronin (2001) dikutip Fandy dan Chandra (2005) dalam Mulyana dan Sufiyanor (2009)

\section{c) Kepercayaan}

Kepercayaan sangat penting bagi hubungan kemitraan atau dalam memelihara pemasaran relasional, hal ini disebabkan karena kepercayaan merupakan pondasi untuk membangun hubungan dalam bisnis jasa. Berry dan Parasuraman (1990) dikutip Japarianto (2014 : 20)menemukan bahwa hubungan perusahaan dengan pelanggan membutuhkan kepercayaan, mengatakan bahwa "trust as the perception of confidence in the Exchange partner's reliability and integrity" yang artinya kepercayaan sebagai persepsi kepercayaan di (dalam) pertukaran integritas dan keandalan bersama.Menurut Morgan dan Hunt dikutip 
Jasfar (2002) dalam Jahroni (2009 : 242) pengertian "kepercayaan yaitu suatu rasa percaya kepada mitra dimana seseorang berhubungan”. Kepercayaan menyangkut kredibilitas mitra dan sekaligus harapan terhadapnya untuk mencapai tujuan (Jahroni, 2009 : 242).

Menurut Ramadania (2002) dalam Jahroni (2009 : 242), indikator kepercayaan adalah

1) Keseluruhan kinerja perusahaan sesuai dengan harapan pelanggan

2) Kepercayaan bahwa perusahaan telah menerapkan prinsip kerja dengan benar dalam operasionalnya

3) Kepercayaan bahwa perusahaan mampu memberikan kualitas layanan yang lebih baik

4) Perusahaan dapat diperhitungkan sebagai perusahaan yang mempunyai reputasi yang baik

5) Perasaan aman ketika menggunakan layanan/jasa perusahaan.

\section{d) Harga}

Stanton (2001) dalam Widyanintyas (2010:20), "menyatakan harga adalah sejumlah nilai yang ditukarkan konsumen dengan manfaat dari memiliki dan menggunakan produk atau jasa yang ditetapkan oleh pembeli atau penjual untuk suatu harga yang sama terhadap semua pembeli". Sedangkan Zeithaml (2000) dalam Widyaningtyas (2010 : 19) berpendapat bahwa "harga adalah apa yang kita dapat dari sesuatu yang telah dikorbankan untuk memperoleh produk atau jasa".

Menurut Natalisa dan Fakhriansyah (2008) dalam Widyaningtyas (2010 : 23-24), menyatakan bahwa pengukuran indikator harga diukur dengan menggunakan faktor kesesuaian harga dengan pelayanan sebagai berikut :

1) Keterjangkauan harga

2) Kesesuaian harga dengan manfaat yang diterima

3) Kesesuaian harga dengan fasilitas

4) Kesesuaian harga dengan jarak yang ditempuh

\section{e) Loyalitas Pelanggan}

Menurut Sheth dan Mittal (2004) dalam Tjiptono (2014 : 393), "loyalitas pelanggan adalah komitmen pelanggan terhadap suatu merek, toko, atau pemasok, berdasarkan sikap yang sangat positif dan tercermin dalam pembelian ulang yang konsisten". Griffin (1995) dikutip Seravina (2008 : 20), mengemukakan bahwa"loyalitas pelanggan adalah komitmen yang kuat dari pelanggan, sehingga bersedia melakukan pembelian ulang terhadap produk atau jasa yang disukai secara konsisten dan dalam jangka panjang, tanpa terpengaruh oleh situasi dan usaha-usaha marketing dari produk lain yang berusaha membuat beralih untuk membeli produk lain tersebut".

Loyalitas dalam industri jasa khususnya jasa pengiriman barang/dokumen adalah merupakan komitmen positif dari pelanggan terhadap layanan yang diterimanya dalam menggunakan jasa tersebut. Indikator loyalitas pelanggan menurut Griffin (2005) dalam Marina (2014 : 160) adalah :

1) Melakukan pembelian berulang secara teratur. 
2) Membeli antarlini produk dan jasa

3) Mereferensikan kepada orang lain

4) Menunjukan kekebalan terhadap tarikan dari pesaing-pesaing

\section{Hipotesis Penelitian}

Hipotesis dari penelitian ini adalah diduga kinerja layanan, kepercayaan, dan harga berpengaruh signifikan secara parsial dan simultan (bersama-sama) terhadap jasa pos express dikota Padang.

\section{Metode Penelitian}

Metode yang digunakan penulis dalam penelitian ini adalah metode kuantitatif. Menurut Sugiyono (2013 : 35-36), "metode kuantitatif diartikan sebagai metode penelitian yang berlandaskan pada filsafat positivisme, digunakan unuk meneliti pada populasi atau sampel tertentu, pengumpulan data menggunakan instrumen penelitian, analisis data bersifat kuantitatif/statistik, dengan tujuan untuk menguji hipotesis yang telah ditetapkan". Metode kuantitatif digunakan pada penelitian ini untuk mengukur dan menganalisis pengaruhkinerja layanan, kepercayaan, dan harga terhadap loyalitas pelanggan jasa pos express di kota Padang.

\section{Populasi, Sampel, dan Teknik Pengambilan Sampel}

Menurut Sugiyono (2013 : 90), "populasi adalah wilayah generalisasi yang terdiri atas: obyek/subyek yang mempunyai kuantitas dan karakteristik tertentu yang ditetapkan oleh peneliti untuk dipelajari dan kemudian ditarik kesimpulannya". Berdasarkan Tabel 1.2, diketahui bahwa jumlah pelanggan yang menggunakan jasa pos express pada tahun berakhir 2014adalah 93.138 orang, maka selanjutnya dinyatakan populasi pada penelitian ini.

Menurut Sugiyono (2013 : 149), "sampel adalah bagian dari jumlah dan karakteristik yang dimiliki oleh populasi tersebut". Dalam suatu penelitian tidak mungkin semua populasi diteliti, dalam hal ini disebabkan oleh keterbatasan biaya dan keterbatasan tenaga dan waktu yang tersedia. Populasi dari penelitian ini adalah 93.138 orang, maka untuk menentukan ukuran sampel penelitian dari populasi tersebut dapat menggunakan teknik slovin dengan rumussebagai berikut (Siregar, $2012: 61$ ) :

$$
\mathrm{n}=\frac{\mathrm{N}}{1+\mathrm{N}(\mathrm{e})^{2}}=\frac{93.138}{1+93.138(10 \%)^{2}}=99,89
$$

Keterangan :

$$
\begin{aligned}
\mathrm{n}= & \text { Jumlah sampel } \\
\mathrm{e} & =\text { Error yang ditolerir }(10 \%) \\
\mathrm{N}= & \text { Jumlah konsumen jasa dengan asumsi masing-masing konsumen } \\
& \text { menggunakan } 1 \text { jasa pos express. }
\end{aligned}
$$


Hasil dari teknik slovin yang digunakan peneliti, diperoleh $n=99,89$. Untuk memudahkan penelitian, maka jumlah sampel dibulatkan menjadi 100 responden.

Menurut Sugiyono (2013 : 15), "teknik sampling adalah merupakan teknik pengambilan sampel". Dalam penelitian ini, peneliti menggunakan teknik non probability sampling. Menurut Sugiyono (2013 : 154), "non probability sampling adalah teknik pengambilan sampel yang tidak memberi peluang atau kesempatan sama bagi setiap unsur atau anggota populasi untuk dipilih menjadi sampel".Teknik non probability sampling yang digunakan peneliti adalah sampling incidental. Menurut Sugiyono (2013 : 156), "samplingincidental adalah teknik penentuan sampel berdasarkan kebetulan, yaitu siapa saja yang secara kebetulan/insidental bertemu dengan peneliti dapat digunakan sebagai sampel, bila dipandang orang yang kebetulan ditemui itu cocok sebagai sumber data".

\section{Teknik Analisis Data}

Pada penelitian kuantitatif kegiatan analisis datanya meliputi pengolahan data dan penyajian data, melakukan perhitungan untuk mendeskripsikan data dan melakukan pengujian hipotesis dengan menggunakan uji statistik (Siregar, 2012 : 125). Menurut Sugiyono (2013 : 238), "kegiatan dalam analisis data adalah: mengelompokan data berdasarkan variabel dan jenis responden, mentabulasi data berdasarkan variabel dari seluruh responden, menyajikan data tiap variabel yang diteliti, melakukan perhitungan untuk menjawab rumusan masalah, dan melakukan perhitungan untuk menguji hipotesis yang telah diajukan”. Pada penelitian ini, pengolahan data dilakukan dengan menggunakan aplikasi SPSS (Statistical Product and Service Solution) Statistic 20. Biasanya dalam penelitian kesalahan taksiran ditetapkan terlebih dahulu, yang digunakan adalah 5\% dan $1 \%$ (Sugiyono, $2013: 254$ ).

\section{1) Uji Instrumen Penelitian}

Menurut Sugiyono (2013 : 203), “instrumen yang valid dan reliabel merupakan syarat mutlak untuk mendapatkan hasil penelitian yang valid dan reliabel". Dengan menggunakan instrumen yang valid dan reliabel dalam pengumpulan data, maka diharapkan hasil penelitian akan menjadi valid dan reliabel. Instrumen yang tidak teruji validitas dan reliabilitasnya bila digunakan untuk penelitian akan menghasilkan data yang sulit dipercaya kebenarannya (Sugiyono, 2013 : 204). Uji instrumen penelitian dicobakan pada sampel dari mana populasi diambil. Jumlah sampel yang digunakan untuk pengujian sekitar 30 responden (Sugiyono, $2013: 207$ ).

\section{a) Uji Validitas (Validitas Konstruk)}

Menurut Sugiyono (2013 : 206), instrumen yang mempunyai validitas konstruksi, jika instrumen tersebut dapat digunakan untuk mengukur gejala sesuai dengan yang didefinisikan. Menurut Siregar (2012 : 77), "konstruk adalah kerangka dari suatu konsep, validitas konstruk adalah validitas yang berkaitan dengan kesanggupan suatu alat ukur dalam mengukur pengertian suatu konsep yang diukurnya". Suatu Instrumen penelitian dikatakan valid, bila (Siregar, $2012: 77$ ) : 
1. Koefisien korelasi product moment melebihi 0,3 (Azwar, 1992; Sugiyono, 1999).

2. Koefisien korelasi product moment $>$ r-tabel $(\alpha ; n-2) n=$ jumlah sampel

3. Nilai sig $\leq \alpha$.

\section{b) Uji Reliabilitas}

Menurut Siregar (2012 : 90), "teknik alpha cronbach dapat digunakan untuk menentukan apakah suatu instrumen penelitian reabel atau tidak, bila jawaban yang diberikan responden berbentuk skala, seperti 1-3, 1-5, dan 1-7 atau jawaban responden yang menginterprestasikan penilaian sikap". Kriteria suatu instrumen penelitian dikatakan reliabel dengan menggunakan teknik alpha cronbach, bila koefisien reliabilitas $\left(\mathrm{r}_{11}\right)>0,6$ (Siregar, $2012:$ 90).

\section{2) Analisis Deskriptif}

Menurut Santi (2014 : 86), "analisis ini digunakan untuk melihat gambaran secara umum tentang variabel yang diteliti dengan analisis presentase". Masing-masing variabel penelitian dianalisis ke dalam tabel distribusi frekuensi, kemudian dilanjutkan dengan mencari presentase jawaban responden, menghitung nilai rata-rata, skor total, dan tingkat pencapaian responden (TCR).

\section{3) Analisis Regresi Linier Berganda}

Penelitian ini menggunakan tiga variabel bebas (independent) dan satu variabel terikat (dependent), sehingga rumus regresi liniar berganda dari penelitian ini adalah sebagai berikut (Siregar, $2012: 443)$ :

$$
Y=a+b_{1} X_{1}+b_{2} X_{2}+b_{3} X_{3}+e
$$

Keterangan :

$\begin{array}{ll}\mathrm{X}_{1} & =\text { Kinerja Layanan } \\ \mathrm{X}_{2} & =\text { Kepercayaan } \\ \mathrm{X}_{3} & =\text { Harga } \\ \mathrm{Y} & =\text { Loyalitas Pelanggan } \\ \mathrm{a}, \mathrm{b}_{1}, \mathrm{~b}_{2}, \mathrm{~b}_{3} & =\text { Konstanta } \\ \mathrm{e} & =\text { Standard error }\end{array}$

\section{4) Uji Hipotesis}

Menurut Siregar (2012 : 438), untuk menguji kevalidan persamaan regresi linier berganda digunakan dua cara, yaitu hipotesis berdasarkan uji $\mathrm{F}$ (secara simultan) dan uji-t (parsial) dan hipotesis berdasarkan teknik probabilitas. Untuk mengambil keputusan dan kesimpulan dari hasil uji $t$ dan uji $F$ yang diperoleh, maka perlu ditentukan hipotesis penelitian dalam bentuk hipotesis nol (Ho) dan hipotesis penelitian (Ha). Menurut Siregar (2012 : 66), "hipotesis nol (Ho) adalah hipotesis yang menyatakan ketidakbenaran dari suatu fenomena atau menyatakan tidak ada hubungan antara dua variabel atau lebih". Sedangkan hipotesis penelitian (Ha) merupakan anggapan dasar peneliti terhadap suatu masalah yang sedang dikaji, peneliti menganggap benar hipotesisnya, yang kemudian akan dibuktikan secara empiris melalui pengujian hipotesis dengan 
mempergunakan data yang diperoleh selama melakukan penelitian (Siregar, 2012 :66).

\section{a) Uji t}

Menurut Siregar (2012 : 194), "Uji ini digunakan untuk mengetahui kebenaran pernyataan atau dugaan yang dihipotesiskan oleh peneliti”. Tujuan dilakukan uji t adalah untuk mengukur pengaruh variabel-variabel bebas secara parsial (terpisah) terhadap variabel terikat. Uji t dilakukan dengan membandingkan $t_{\text {hitung }}$ dan $t_{\text {tabel }}$ serta nilai signifikan dengan taraf signifikan $(\alpha)$ yang digunakan.

\section{b) Uji F}

Menurut Siregar (2012 : 439), "Hipotesis berdasarkan uji F hanya digunakan untuk mengetahui apakah variabel-variabel bebas secara bersama-sama (simultan) mempengaruhi satu variabel tak bebas". Uji $F$ dilakukan dengan membandingkan $F_{\text {hitungdengan }} \mathrm{F}_{\text {tabel}}$ serta nilai probabilitas yang diperoleh dengan tingkat signifikan yang digunakan.

\section{5) Koefisien Determinasi}

Menurut Siregar (2012 : 338), "koefisien determinasi adalah angka yang menyatakan atau digunakan untuk mengetahui kontribusi atau sumbangan yang diberikan oleh satu variabel atau lebih X (bebas) terhadap variabel Y (terikat)". Koefisien determinasi yang digunakan adalah Adjusted R Square karena lebih dapat dipercaya dalam mengevaluasi model regresi (Sumiarti, Yenida, dan Sarmiadi, 2014 : 112).

\section{Hasil Dan Pembahasan \\ Deskripsi Hasil Penelitian}

Hasil dari penelitian yang telah dilakukan terhadap 100 responden pelanggan layanan jasa pos express, diperoleh beberapa karakteristik yang dapat dilihat dari klasifikasi responden sebagai berikut :

\section{a. Jenis Kelamin}

Tabel 4.1.

Responden Berdasarkan Jenis Kelamin

\begin{tabular}{|l|c|c|}
\hline \multicolumn{1}{|c|}{ Jenis Kelamin } & Jumlah & Persentase (\%) \\
\hline Laki-laki & 48 & 48 \\
\hline Perempuan & 52 & 52 \\
\hline Total & 100 & 100 \\
\hline
\end{tabular}

Sumber : Olahan Data Primer 2015

Berdasarkan Tabel 4.1, diketahui bahwa responden berjenis kelamin perempuan lebih banyak dari pada responden berjenis kelamin laki-laki dimana dari 100 responden yang diperoleh dalam penelitian ini terdapat 52 orang (52\%) berjenis kelamin perempuan dan 48 orang $(48 \%)$ berjenis kelamin laki-laki. Hal ini menunjukan bahwa sebagian besar pelanggan jasa pos express adalah perempuan. 


\section{b. Usia}

Tabel 4.2.

Responden Berdasarkan Usia

\begin{tabular}{|l|c|c|}
\hline \multicolumn{1}{|c|}{ Usia } & Frekuensi & Presentase $(\%)$ \\
\hline 15-25 tahun & 42 & 42 \\
\hline 26-35 tahun & 33 & 33 \\
\hline 36-45 tahun & 15 & 15 \\
\hline 46-55 tahun & 10 & 10 \\
\hline Total & 100 & 100 \\
\hline
\end{tabular}

Sumber : Olahan Data Primer 2015

Dari Tabel 4.2, diketahui bahwa responden dalam penelitian ini lebih banyak berusia 15-25 tahun dengan jumlah 42 orang (42\%), sedangkan yang berusia 25-35 tahun dengan jumlah 33 orang (33\%), berusia 35-45 tahun dengan jumlah 15 orang (15\%) dan responden yang paling sedikit adalah berusia 45-55 tahun dengan jumlah 10 orang (10\%). Hal ini menunjukan bahwa pelanggan jasa pos express lebih banyak berusia 15-25 tahun.

\section{c. Pekerjaan}

Tabel 4.3.

Responden Berdasarkan Pekerjaan

\begin{tabular}{|l|c|c|}
\hline \multicolumn{1}{|c|}{ Pekerjaan } & Frekuensi & Presentase (\%) \\
\hline Pelajar/Mahasiswa & 22 & 22 \\
\hline Pegawai Negeri Sipil & 15 & 15 \\
\hline Pegawai BUMN & 5 & 5 \\
\hline Karyawan Swasta & 28 & 28 \\
\hline Wiraswasta & 14 & 14 \\
\hline Pedagang & 9 & 9 \\
\hline Dan Lain-Lain & 7 & 7 \\
\hline Total & 100 & 100 \\
\hline
\end{tabular}

Sumber : Olahan Data Primer 2015

Dari Tabel 4.3, diketahui bahwa pekerjaan responden terbanyak adalah karyawan swasta dengan jumlah 28 orang (28\%). Sisanya tersebar dalam berbagai jenis pekerjaan lain, yaitu 22 orang (22\%) adalah pelajar/mahasiswa, 15 orang (15\%) merupakan pegawai negeri sipil, 5 orang (5\%) merupakan pegawai BUMN, 14 orang $(14 \%)$ merupakan wiraswasta, 9 orang $(9 \%)$ merupakan pedagang, dan lain-lain sebanyak 7 orang (7\%). Hal ini menunjukan pelanggan jasa pos express banyak yang berkerja sebagai karyawan swasta. 


\section{d. Pendidikan}

Tabel 4.4.

Responden Berdasarkan Pendidikan Terakhir

\begin{tabular}{|l|r|r|}
\hline \multicolumn{1}{|c|}{ Pendidikan Terakhir } & Frekuensi & Presentase (\%) \\
\hline SMP & 3 & 3 \\
\hline SMA & 34 & 34 \\
\hline SMK & 18 & 18 \\
\hline D1 & 6 & 6 \\
\hline DIII & 12 & 12 \\
\hline S1 & 23 & 23 \\
\hline S2 & 4 & 4 \\
\hline Total & 100 & $100 \%$ \\
\hline
\end{tabular}

Sumber : Olahan Data Primer 2015

Dari Tabel 4.4, diketahui bahwa responden yang berpendidikan terakhir SMA (Sekolah Menengah Atas) merupakan responden terbanyak dengan jumlah 34 orang (34\%). Sedangkan S1 (Sarjana) terdapat 23 orang (23\%), SMK (Sekolah Menengah Kejuruan) terdapat 18 orang (18\%), DIII (Diploma) terdapat 12 orang (12\%), D1 (Diploma) terdapat 6 orang (6\%), S2 (Pasca Sarjana) terdapat 4 orang (4\%), dan responden yang berpendidikan terakhir SMP (Sekolah Menengah Pertama) merupakan responden yang paling sedikit dengan jumlah 3 orang (3\%). Hal ini menunjukan bahwa pelanggan jasa pos express lebih banyak berpendidikan terakhir SMA (Sekolah Menengah Atas).

Analisis Pengaruh Kinerja Layanan, Kepercayaan, dan Harga Terhadap Loyalitas Pelanggan Jasa Pos ExpressDi Kota Padang

\section{a. Regresi Liniar Berganda}

Tabel 4.14.

Coefficients $^{\text {a }}$

\begin{tabular}{|c|c|c|c|c|c|c|}
\hline \multirow{2}{*}{\multicolumn{2}{|c|}{ Model }} & \multicolumn{2}{|c|}{$\begin{array}{l}\text { Unstandardized } \\
\text { Coefficients }\end{array}$} & \multirow{2}{*}{$\begin{array}{c}\begin{array}{c}\text { Standardized } \\
\text { Coefficients }\end{array} \\
\text { Beta } \\
\end{array}$} & \multirow[t]{2}{*}{$\mathrm{t}$} & \multirow[t]{2}{*}{ Sig. } \\
\hline & & $\mathrm{B}$ & Std. Error & & & \\
\hline \multirow{4}{*}{1} & (Constant) & -1.787 & 2.574 & & -.694 & .489 \\
\hline & Kinerja Layanan & .136 & .043 & .282 & 3.153 & .002 \\
\hline & Kepercayaan & .329 & .082 & .325 & 4.003 & .000 \\
\hline & Harga & .237 & .071 & .289 & 3.356 & .001 \\
\hline
\end{tabular}

a. Dependent Variable: Loyalitas Pelanggan

Sumber : Olahan Data Primer 2015

Berdasarkan Tabel 4.14, diperoleh persamaan regresi berganda sebagai berikut :

$$
Y=-1,787+0,136 X_{1}+0,329 X_{2}+0,237 X_{3}+e
$$


Dari persamaan tersebut dapat dianalisis beberapa hal, antara lain :

1) Nilai konstanta diperoleh sebesar $-1,787$ artinya tanpa adanya variabel kinerja layanan, kepercayaan, dan harga $(\mathrm{X} 1, \mathrm{X} 2$, dan $\mathrm{X} 3$ adalah 0$)$ maka loyalitas pelanggan bernilai negatif sebesar $-1,787$.

2) Koefisien regresi variabel kinerja layanan diperoleh sebesar 0,136 artinya jika kinerja layanan meningkat 1 (satuan) dengan asumsi variabel kepercayaan (X2), harga (X3) dan konstanta (a) adalah nol (0), maka loyalitas pelanggan jasa pos express di kota Padang mengalami peningkatan sebesar 0,136.

3) Koefisien regresi variabel kepercayaan diperoleh sebesar 0,329 artinya jika kepercayaan meningkat 1 (satuan) dengan asumsi variabel kinerja layanan (X1), harga (X3) dan konstanta (a) adalah nol (0), maka loyalitas pelanggan jasa pos express di kota Padang mengalami peningkatan sebesar 0,329.

Koefisien regresi variabel harga diperoleh sebesar 0,237 artinya jika harga meningkat 1 (satuan) dengan asumsi variabel kinerja layanan (X1), kepercayaan (X2), dan konstanta (a) adalah nol (0), maka loyalitas pelanggan jasa pos express di kota Padang mengalami peningkatan sebesar 0,237.

\section{b. Uji t}

Tabel 4.15.

Coefficients $^{\mathbf{a}}$

\begin{tabular}{|c|c|c|c|c|c|c|}
\hline \multirow{2}{*}{\multicolumn{2}{|c|}{ Model }} & \multicolumn{2}{|c|}{$\begin{array}{c}\text { Unstandardized } \\
\text { Coefficients }\end{array}$} & \multirow{2}{*}{$\begin{array}{c}\begin{array}{c}\text { Standardized } \\
\text { Coefficients }\end{array} \\
\text { Beta }\end{array}$} & \multirow[t]{2}{*}{$\mathrm{t}$} & \multirow[t]{2}{*}{ Sig. } \\
\hline & & B & Std. Error & & & \\
\hline \multirow{4}{*}{1} & (Constant) & -1.787 & 2.574 & & -.694 & .489 \\
\hline & Kinerja Layanan & .136 & .043 & .282 & 3.153 & .002 \\
\hline & Kepercayaan & .329 & .082 & .325 & 4.003 & .000 \\
\hline & Harga & .237 & .071 & .289 & 3.356 & .001 \\
\hline
\end{tabular}

a. Dependent Variable: Loyalitas Pelanggan

Sumber : Olahan Data Primer 2015

Berdasarkan Tabel 4.15, maka dapat diketahui dan disimpulkan sebagai berikut :

a) Variabel kinerja layanan terhadap loyalitas pelanggan

Diketahui $t_{\text {hitung }}$ kinerja layanan $=3,153$ dan nilai sig $=0,002$ dimana diperoleh $t_{\text {hitung }} 3,153>\mathrm{t}_{\text {tabel }(0,025,97)}=1,985$ serta nilai $\operatorname{sig}=0,002<\alpha=0,025$; maka Ho ditolak dan Ha diterima dengan arti kinerja layanan berpengaruh signifikan terhadap loyalitas pelanggan pos expresss PT. Pos Indonesia (Persero) Padang.

b) Variabel kepercayaan terhadap loyalitas pelanggan

Diketahui $t_{\text {hitung }}$ kepercayaan $=4,003$ dan nilai sig $=0,000$ dimana diperoleh $\mathrm{t}_{\text {hitung }}=4,003>\mathrm{t}_{\text {tabel }(0,025,97)}=1,985$ dan nilai $\operatorname{sig}=0,000<\alpha=0,025$; maka Ho ditolak dan $\mathrm{Ha}$ diterima dengan arti kepercayaan berpengaruh signifikan terhadap loyalitas pelanggan pos expresss PT. Pos Indonesia (Persero) Padang.

c) Variabel harga terhadap loyalitas pelanggan 
Diketahui thitung harga $=3,356$ dan nilai sig $=0,001$ dimana diperoleh $\mathrm{t}$ hitung $=$ $3,356>\mathrm{t}_{\text {tabel }(0,025,97)}=1,985$ dan nilai sig $=0,001<\alpha=0,025$; maka Ho ditolak dan Ha diterma dengan arti harga berpengaruh signifikan terhadap loyalitas pelanggan pos expresss PT. Pos Indonesia (Persero) Padang.

\section{c. Uji F}

Tabel 4.16.

ANOVA ${ }^{\mathrm{a}}$

\begin{tabular}{|l|l|r|r|r|r|r|}
\hline \multicolumn{2}{|l|}{ Model } & $\begin{array}{c}\text { Sum of } \\
\text { Squares }\end{array}$ & \multicolumn{1}{c|}{ df } & $\begin{array}{c}\text { Mean } \\
\text { Square }\end{array}$ & F & Sig. \\
\hline \multirow{3}{*}{1} & Regression & 695.259 & 3 & 231.753 & 32.037 & $.000^{\mathrm{b}}$ \\
\cline { 2 - 8 } & Residual & 694.451 & 96 & 7.234 & & \\
\cline { 2 - 8 } & Total & 1389.710 & 99 & & & \\
\hline
\end{tabular}

a. Dependent Variable: Loyalitas Pelanggan

b. Predictors: (Constant), Harga, Kepercayaan, Kinerja Layanan

Sumber : Olahan Data Primer 2015

Berdasarkan Tabel 4.16, diperoleh nilai $\mathrm{F}$ hitung $=32,037$ dengan nilai sig $=0,000$. Dengan membandingkan $\mathrm{F}_{\text {hitung }}=32,037>\mathrm{F}_{\text {tabel }}(0,05)(3,96)=2,70$ dan nilai sig $=0,000<0,05$; maka dapat disimpulkan Kinerja layanan, kepercayaan, dan harga secara simultan (bersama-sama) berpengaruh signifikan terhadap loyalitas pelanggan jasa pengiriman pos express PT. Pos Indonesia (Persero) Padang.

\section{d. Koefisien Determinasi $\left(\mathbf{R}^{2}\right)$}

Tabel 4.17.

Model Summary ${ }^{b}$

\begin{tabular}{|l|r|r|r|r|}
\hline $\begin{array}{l}\text { Mode } \\
1\end{array}$ & \multicolumn{1}{|c|}{$\mathrm{R}$} & R Square & $\begin{array}{c}\text { Adjusted R } \\
\text { Square }\end{array}$ & $\begin{array}{c}\text { Std. Error of } \\
\text { the Estimate }\end{array}$ \\
\hline 1 & $.707^{\mathrm{a}}$ & .500 & .485 & 2.690 \\
\hline
\end{tabular}

a. Predictors: (Constant), Harga, Kepercayaan, Kinerja Layanan

b. Dependent Variable: Loyalitas Pelanggan

Sumber : Olahan Data Primer 2015

Berdasarkan Tabel 4.17, diperoleh nilai AdjustedR Square $=0,485$ sehingga kontribusi yang diberikan oleh kinerja layanan, kepercayaan dan harga terhadap loyalitas pelanggan adalah $100 \% \times 0,485=48,50 \%$. Maka dapat disimpulkan bahwa kemampuan variabel independen, yaitu kinerja layanan, kepercayaan, dan harga dalam menjelaskan variabel dependen, yaitu loyalitas pelanggan adalah sebesar 48,50 \% dan selebihnya dijelaskan oleh faktor lain yang tidak dijelaskan dalam model regresi sebesar 51,50\%, diasumsikan oleh peneliti yang mempengaruhi loyalitas pelanggan seperti : kualitas produk, promosi, kepuasan pelanggan, citra, dan lain-lainnya. 


\section{Kesimpulan}

Berdasarkan hasil penelitian dan pembahasannya, maka dapat diambil kesimpulan sebagai berikut:

1. Berdasarkan analisis regresi linear berganda, kinerja pelayanan memberikan pengaruh positif terhadap peningkatan loyalitas pelanggan dimana peningkatan kinerja layanan sebesar 1 (satuan) mampu meningkatkan loyalitas pelanggan sebesar 0,136 satuan. Hasil uji t pada kinerja layanan terhadap loyalitas pelanggan dimana nilai $\mathrm{t}_{\text {hitung }} 3,153>\mathrm{t}_{\text {tabel }} 1,985$ serta nilai sig $0,002<0,025$ ditemukan bahwa kinerja layanan berpengaruh signifikan terhadap loyalitas pelanggan. Dengan demikian hipotesis pertama, yaitu diduga kinerja layanan berpengaruh signifikan terhadap loyalitas pelanggan dapat diterima.

2. Berdasarkan analisis regresi linear berganda, kepercayaan memberikan pengaruh positif terhadap peningkatan loyalitas pelanggan dimana peningkatan kepercayaan sebesar 1 (satuan) mampu meningkatkan loyalitas pelanggan sebesar 0,329 satuan. Hasil uji t pada kepercayaan terhadap loyalitas pelanggan dimana nilai $t_{\text {hitung }} 4,003>\mathrm{t}_{\text {tabel }} 1,985$ dan nilai sig $0,000<0,025$ ditemukan bahwa kepercayaan berpengaruh signifikan terhadap loyalitas pelanggan. Dengan demikian hipotesis kedua, yaitu diduga kepercayaan berpengaruh signifikan terhadap loyalitas pelanggan dapat diterima.

3. Berdasarkan analisis regresi linear berganda, harga memberikan pengaruh positif terhadap peningkatan loyalitas pelanggan dimana peningkatan harga sebesar 1 (satuan) mampu meningkatkan loyalitas sebesar 0,237 satuan. Hasil uji t pada harga terhadap loyalitas pelanggan dimana nilai $t_{\text {hitung }} 3,356>\mathrm{t}_{\text {tabel }}$ 1,984 dan nilai sig 0,001 < 0,025 ditemukan bahwa harga berpengaruh signifikan terhadap loyalitas pelanggan. Dengan demikian hipotesis ketiga, yaitu diduga harga berpengaruh signifikan terhadap loyalitas pelanggan dapat diterima.

4. Berdasarkan hasil uji $\mathrm{F}$ ditemukan nilai $F_{\text {hitung }} 32,037>t_{\text {tabel }}$ 2,70 dan nilai sig $0,000<0,05$ menunjukan bahwa kinerja layanan, kepercayaan, dan harga secara bersama-sama berpengaruh signifikan terhadap loyalitas pelanggan. Dengan demikian hipotesis keempat, yaitu diduga kinerja layanan, kepercayaan, dan harga secara simultan (secara bersama-sama) berpengaruh signifikan terhadap loyalitas pelanggan dapat diterima. Hasil koefisien determinasi dari penelitian ini menunjukan kemampuan variabel kinerja layanan, kepercayaan dan harga dalam menjelaskan variabel loyalitas pelanggan adalah 48,50\% dan selebihnya dijelaskan oleh faktor lain yang mempengaruhi loyalitas pelanggan sebesar 51,50\% diasumsikan oleh peneliti yang mempengaruhi loyalitas pelanggan seperti : kualitas produk, promosi, kepuasan pelanggan, citra, dan lain-lainya.

\section{Saran}

Berdasarkan kesimpulan dari hasil penelitian diatas, maka dapat dikemukakan saran dari penelitian ini adalah sebagai berikut :

1. Manajemen PT. Pos Indonesia (Persero) Padang untuk jasa pos express di kota Padang diharapkan agar lebih meningkatkan kinerja layanan, kepercayaan, dan harga karena dari hasi regresi diketahui variabel kinerja layanan, kepercayaan, 
dan harga mempunyai pengaruh positif terhadap loyalitas pelanggan jasa pos express di kota Padang.

2. Layanan jasa pos express di kota Padang diharapkan lebih meningkatkan kinerja layanan, terutama aspek waktu tunggu agar lebih diminimalkan dari waktu tunggu yang sebelumnya sehingga waktu tunggu pelanggan tidak terlalu lama dan kinerja layanan pada waktu tunggu dapat lebih baik. Sedangkan pada sikap karyawan dalam memberikan layanan kepada konsumen sudah termasuk kategori baik, agar lebih ditingkatkan lagi sehingga kinerja layanan jasa pos express sesuai dengan yang diharapkan.

3. Kepercayaan pelanggan yang berada pada kriteria baik diharapakan lebih ditingkatkan lagi, terutama pada aspek kepercayaan bahwa perusahaan telah menerapkan prinsi kerja dengan benar dalam operasionalnya agar dapat lebih baik. Sedangkan pada kepercayaan bahwa perusahaan mampu memberikan kualitas layanan yang lebih baik sudah termasuk kategori baik, agar lebih ditingkatkan lagi sehingga kepercayaan pelanggan pada layanan jasa pos express sesuai dengan yang diharapkan.

4. Kesesuaian harga dengan pelayanan jasa pos express yang diterima pelanggan diharapkan lebih tingkatkan lagi, terutama aspek kesesuaian harga dengan fasilitas yang diterima dan aspek keterjangkauan harga sehingga dapat lebih baik lagi. dansesuai dengan yang diharapkan. 


\section{DAFTAR PUSTAKA}

Dharmayanti, Diah. 2006. Analisis Dampak Service Performance dan Kepuasan Sebagai Moderating Variabel Terhadap Loyalitas Nasabah. Jurnal Manajemen Pemasaran. Vol. 1. No. 1. (April 2006)

Jahroni. 2009. Pengaruh Kualitas Layanan Terhadap Loyalitas Nasabah Melalui Kepuasan, Komitmen, Kepercayaan Pada Bank Central Asia Tbk. Jurnal Akuuntansi, Manajemen Bisnis dan Sektor Publik (JAMBSP). Vol. 5. No. 3. (Juni 2009)

Japarianto, Edwin. 2014. Evaluasi Customer PT Pos Indonesia Ditinjau Dari Kepuasan Kepercayaan Dan Switching Barriers. Junal Manajemen Pemasaran. Vol. 8. No. 1. (April 2014)

Kurniasih, Indah Dwi. 2012. Pengaruh Harga Dan Kualitas Pelayanan Terhadap Loyalitas Pelanggan Melalui Variabel Kepuasan. Jurnal Administrasi Bisnis.Volume 1. Nomor 1. (September 2012)

Lupiyoadi, Rambat. 2006. Manajemen Pemasaran Jasa Edisi Revisi. Salemba Empat. Jakarta

Marina, Sandriana, Andi Darmawati dan Indra Setiawan. 2014. Pengaruh Kualitas Pelayanan terhadap Loyalitas Pelanggan Pada Perusahaan Penerbangan Full Service Airlines. Jurnal Manajemen Transportasi dan Logistik. Vol. 01. No. 02. (Juli 2014)

Mulyana, dan Sufiyanor. 2009. Analisis Dampak Service Performance dan Kepuasan terhadap Loyalitas Pelanggan. Jurnal. Sultan Agung. Vol XLV. No.199. (September-Nopember 2009)

Murti, Sasanti Herdina. 2013. Pengaruh Dimensi Relantionship Marketing Terhadap Loyalitas Pelanggan. Management Analysis Journal. Volume 1. Nomor 2. ISSN 2252-6552

Nugroho, Adi Wahyu. 2013. Pengaruh Kinerja Layanan. Kepercayaan. Dan Kepuasan Terhadap Loyalitas Konsumen Dalam Menggunakan Jasa Pengiriman Barang. Diponegoro Journal Of Management. Volume 2. Nomor 3. Tahun 2013. Halaman 2

Putra, Arnes. 2012. Pengaruh Kualitas, Desain, Dan Harga Terhadap Keputusan Pembelian Tipe Sepeda Motor Honda Di Kota Padang. Skripsi. Fakultas Ekonomi. Universitas Taman Siswa Padang 
Santi, Elfitri. 2014. Pengaruh Harga dan Promosi Penjualan Terhadap Keputusan Pembelian Konsumen Pada CV. Jaya Herbal Cabang Padang.Jurnal Manajemen dan Kewirausahaan. Volume 5. Nomor 1. (Januari 2014). ISSN : $2086-5031$

Seravina, Marisa.2008. Penerapan Corporate Social Responsibility (CSR) Terhadap Loyalitas Nasabah Tabungan Britama. Skripsi. Fakultas Ekonomi dan Manajemen. Institut Pertanian Bogor

Siregar, Syofian. 2012. Statistik Parametrik untuk Penelitian Kuantitatif. Jakarta : PT Bumi Aksara

Sugiyono. 2013. Metode Penelitian Manajemen. Bandung: Alfabeta

Tjiptono, Fandy. 2014. Pemasaran Jasa - Prinsip, Penerapan, dan Penelitian. Ed. I. Andi Offset. Yogyakarta

Yenida, Sumiarti, Sarmiadi. 2014. Analisis Pengaruh Strategi Bauran Pemasaran, Sistem Pendidikan Perguruan Tinggi, Status Akreditasi Terhadap Keputusan Mahasiwa Dalam Memilih Jurusan Administrasi Niaga Politeknik Negeri Padang. e-jurnal Universitas Tamansiswa Padang.

Widyaningtyas, Richa. 2010. Faktor-Faktor Yang Mempengaruhi Loyalitas Serta Dampaknya Pada Kepuasan Konsumen Dalam Menggunakan Jasa Kereta Api Harina. Fakultas Ekonomi. Universitas Diponegoro. Semarang 